\title{
TINJAUAN PENGELOLAAN LIMBAH DI TAMAN SATWA BALI ZOO SUKAWATI GIANYAR TAHUN 2017
}

\author{
I Gusti Ayu Aris Wijayanthi ${ }^{1}$, Nengah Notes ${ }^{2}$, I Gusti Ayu Made Aryasih ${ }^{3}$
}

Abstract.Garbage is commonly found in public places which become a public health problem because public place is a meeting place of all kinds of society with all kinds of diseases possessed by the society. Trash is also included in the waste. Where waste is all solid and liquid materials are discharges derived from human activities individually as well as the results of other activity activities. This type of research is used by observation (direct observation) by using descriptive method. Sources of waste contained in Bali Zoo come from visitors or from activities or activities carried out at Bali Zoo Wildlife Park. Where from the implementation of the research obtained results that is on the solid waste management (garbage) obtained results meet the requirements while in the liquid waste is said not to qualify. The conclusion of this research is the number of waste management facilities that need to be considered, such as waste bins that do not have a lid and the absence of waste water treatment plant facilities in Bali Zoo.

\section{Keywords: waste, sanitation, wildlife park}

Masalah sampah di Indonesia merupakan masalah yang rumit karena kurangnya pengertian masyarakat terhadap akibat yang dapat ditimbulkan oleh sampah dan kurangnya biaya pemerintah untuk mengusahakan pembuangan sampah yang baik dan memenuhi syarat. Sampah banyak ditemukan pada tempat-tempat umum yang menjadi masalah kesehatan masyarakat karena tempat umum merupakan tempat bertemunya masyarakat dengan segala macam penyakit.

Limbah adalah semua benda yang berbentuk padat (solid waste) dan cair (liquid waste) merupakan bahan buangan yang berasal dari aktivitas manusia secara perorangan maupun hasil aktivitas kegiatan lainnya(1).Limbah cair merupakan gabungan atau campuran dari air dan bahan-bahan pencema yang terbawa oleh air, baik dalam keadaan terlarut maupun tersuspensiyang terbuang dari sumber domestik dan pada saat tertentu tercampur dengan air tanah, air permukaan, atau air hujan(2) sedangkan limbah padat atau sampah erat kaitannya dengan kesehatan masyarakat, karena dari sampah tersebut dapat hidup berbagai mikroorganisme penyebab penyakit, dan juga binatang serta serangga pemindah atau penyebar penyakit (vektor)(3).

Taman Satwa Bali Zoo merupakan taman satwa yang cukup diminati bagi wisatawan. Dimana Taman Satwa Bali Zoo ini terletak di Jalan Raya Singapadu Banjar Apuan, Desa Singapadu, Sukawati, Gianyar, Bali. Berdasarkan survei pendahuluan masalah yang terkait limbah di Taman Satwa Bali Zoo ini bahwa masih adanya wisatawan yang membuang sampah sembarangan dan membuang tissue serta pembalut kedalam closet yang berada di toilet 
Bali Zoo.Penulis tertarik untuk melakukan penelitian dan melakukan observasi langsung di Bali Zoo ini dengan tujuan untuk mengetahui pengelolaan limbah baik pada proses pengelolaan limbah padat (sampah) dan limbah cair. Perlunya adanya pengelolaan limbah yang baik di Bali Zoo sehingga tidak menganggu kenyamanan dan kebersihan taman satwa

\section{METODE}

Dalam penelitian ini penulis menggunakan penelitian deskriptif yakni membuat deskripsi atau gambaran secara sistematis, faktual, dan akurat mengenai fakta-fakta, sifat-sifat serta hubungan antara fenomena yang diteliti(4) Penelitian dilakukan dengan cara melakukan sebuah pengamatan menggunakan lembar observasi untuk mengetahui pengelolaan limbah di Taman Satwa Bali Zoo Sukawati, Gianyar tahun 2017.Dalam penelitian ini yang dijadikan unit analisis adalah para pekerja yang mengelola limbah. Obyek dalam penelitian ini adalah proses pengelolaan limbah di Taman Satwa Bali Zoo Sukawati, Gianyar Tahun 2017.

Pengolahan data dalam penelitian masih merupakan data mentah, untuk selanjutnya data tersebut perlu diolah dengan cara editing (memeriksa kembali kekeliruan dalam pengisian), coding (memisahkan jawaban responden), dan tabulasi (menyusun data dalam bentuk tabel)(4). Hasil pengolahan data dalam penelitian ini dihitung dengan menggunakan rumus interval kelaskemudian diberi penilaian atau jumlah skor yakni sebagai berikut(5).
Interval kelas:
$\frac{\text { Nilai Terbesar-Nilai Terkecil }}{\text { Jumlah Kelas Interval }}$
Dalam jumlah pertanyaan untuk meninjau pengelolaan limbah, maka nilai yang didapat pada lembar observasi mendapat nilai "Ya $=1$ " dan "Tidak $=0$ " dengan jumlah kelas interval ialah dua yakni memenuhi syarat dan tidak memenuhi syarat, maka pada pengelolaan limbah padat (sampah) dengan nilai $0-24$ kategori tidak memenuhi syarat sedangkan nilai 25 - 49 kategori memenuhi syarat, pada pengelolaan limbah cair dengan nilai 0 - 6 kategori tidak memenuhi syarat sedangkan nilai $7-12$ kategori memenuhi syarat, dan pada keadaan hygiene sanitasi pengelolaan limbah keseluruhan dengan nilai $0-30$ kategori tidak memenuhi syarat sedangkan dengan nilai 31 - 61 kategori memenuhi syarat.

\section{HASIL DAN PEMBAHASAN \\ Hasil}

1. Proses pengelolaan limbah padat (sampah)

Berdasarkan hasil observasi proses pengelolaan limbah padat (sampah) diketahui bahwa sumber sampah yang terdapat di Taman Satwa Bali Zoo berasal dari pengunjung maupun kegiatan atau aktivitas yang dilaksanakan di Bali Zoo. Sampah ini terdiri dari sampah organik, non organik, dan sampah medis. Sampah tersebut kemudian ditampung menggunakan tempat sampah yang kemudian dibawa ke TPS menggunakan kendaraan pengangkut sampah dan dipilah kembali, sampah organik diolah menjadi kompos yang kemudian digunakan untuk tanaman yang ada di Bali Zoo dan sisa sampah restoran 
berupa organik diberikan untuk warga sebagai pakan ternak babi, sedangkan sampah non organik dijual ke pemulung, pada limbah padat yang tidak dimanfaatkan kembali dibuang ke TPA Temesi dan bekerjasama dengan jasa pengangkutan sampah, dan sampah medis yang dihasilkan klinik Bali Zoo hanya ditampung sementara pada tempat sampah yang kemudian diserahkan langsung pada pihak ke tiga untuk proses lebih lanjut,proses pembuangan akhir sisa sampah yang tidak dijual dan tidak dapat diolah kembali dibuang pada TPA Temesi dan dikelola lebih lanjut oleh pihak DKP sehingga observasi tidak dilakukan lebih lanjut oleh karena itu pengelolaan sampah di Taman Satwa Bali Zoo hanya sampai pada tahap pengolahan sampah. Adapun hasil yang didapat dalam proses pengelolaan limbah padat (sampah) menggunakan lembar observasi di Taman Satwa Bali Zoo dari tahap pengumpulan sampah, tahap pengangkutan sampah, dan tahap pengolahan sampah. Dimana didapatkan nilai 38 dari 49 pertanyaan yakni memenuhi syarat.

2. Proses pengelolaan limbah cair

$$
\text { Berdasarkan hasil }
$$
pengamatan menggunakan lembar observasi proses pengelolaan limbah cair diketahui berasal dari limbah restoran dan toilet dimana pada limbah cair hanya disalurkan langsung pada tempat penampungan air limbah hanya disalurkan langsung pada tempat penampungan air limbah tanpa pengolahan apapun seperti pada wawancara awal mengatakan limbah cair disaring menggunakan batu bata merah, ijuk, karbon ately. Sedangkan pada toilet disalurkan menuju kearah septic tank yangmenghasilkan \pm dua $\mathrm{m}^{3}$ dan terdapat tujuh unit septic tank, sedangkan sumber air yang berasal dari sumur bor, PDAM, dan tangki air/tower air berjumlah 16 unit dengan jarak septic tank ke sumber air adalah 12 - 15 meter. Dari hasil yang didapat dalam proses pengelolaan limbah cair menggunakan lembar observasi di Taman Satwa Bali Zoo didapatkan nilai 5 dari 12 pertanyaan yakni tidak memenuhi syarat.

3. Keadaan hygiene sanitasi pengelolaan limbah secara keseluruhan

Keadaan hygiene sanitasi pengelolaan limbah keseluruhan didapatkan dari proses pengelolaan limbah padat (sampah) dan limbah cair yang sudah dijelaskan di atas didapatkan hasil perhitungan dari rumus interval kelas dengan nilai sebesar 43 dari 61 pertanyaan yakni memenuhi syarat.

Tabel 1

Hasil Penilaian Keadaan Hygiene Sanitasi Pengelolaan Limbah

\begin{tabular}{|c|c|c|c|c|}
\hline \multirow{2}{*}{ Variabel Yang Dinilai } & \multicolumn{2}{|c|}{ Nilai } & \multirow{2}{*}{ Jumlah } & \multirow{2}{*}{ Kategori } \\
\cline { 2 - 3 } & Ya & Tidak & & Memenuhi syarat \\
\hline Pengelolaan limbah padat & 38 & 11 & 49 & Tidak memenuhi syarat \\
\hline Pengelolaan limbah cair & 5 & 7 & 12 & Memenuhi syarat \\
\hline Total & $\mathbf{4 3}$ & $\mathbf{1 8}$ & $\mathbf{6 1}$ & . \\
\hline
\end{tabular}




\section{Pembahasan}

Hasil observasi lapangan pada proses pengelolaan limbah padat (sampah) dengan kategori memenuhi syarat didapatkan dari tahap pengumpulan dan penyimpanan sampah, tahap pengangkutan, dan tahap pemusnahan.Sedangkan pada tempat sampah tidak tersedia tutup, beberapa tempat sampah juga tidak memiliki alas di dalamnyauntuk menjaga wadah tempat sampah tidak mudah berlubang, dan tidak tersedianya anjuran untuk membuang sampah pada tempatnya, pada TPS tidak tersedia dua pintu yang terdiri dari pintu masuk dan pintu untuk mengambil sampah, tidak tersedia lubang ventilasi yang tertutup dengan kawat halus.Kendaraan pengangkut tersebut tidak memiliki tutupsaat mengangkut sampah, beberapa petugas/staf yang bertugas dalam pengelolaan limbah padat (sampah) tidak menggunakan alat pelindung diri seperti sepatu boots dan sarung tangan.

Tempat sampah harus
memenuhi persyaratan yakni kontruksi harus kuat dan tidak mudah bocor, memiliki tutup dan mudah dibuka tanpa mengotori tangan, mudah diangkut oleh satu orang dan maksimal sampah ditampung selama tiga hari(6) Tempat sampah yang tidak memiliki alas didalamnya dimana tujuan dari alas didalam tempat sampah untuk menjaga wadah tempat sampah tidak mudah berlubang.Tidak tersedianya anjuran untuk membuang sampah pada tempatnya dapat memungkinkan pengunjung membuang sampah sembarangan dan tempat sampah yang tidak memiliki tutup dapat memungkinkan perkembangbiakan serangga dan tikus yang dapat menjadi pembawa penyakit.

Untuk membangun TPS persyaratan yang harus dipenuhi yakni memiliki dua pintu yaitu pintu masuk dan pintu untuk mengambil sampah, memiliki lubang ventilasi yang tertutup kawat halus untuk mencegah lalat dan binatang lain masuk ke dalam TPS, terdapat keran air untuk membersihkan, TPS mudah dijangkau masyarakat, TPS tidak menjadi tempat tinggal sarang lalat dan tikus(6). Pengangkutan sampah ini adalah pemindahan sampah dari tempat sampah ke tempat pengumpulan menggunakan kendaraan dengan syarat yakni semua bak kendaraan pengangkut sampah harus terbuat dari bahan logam atau melapisi bagian dalam dinding bak dan lantai dengan bahan logam, semua kendaraan untuk pengangkutan sampah selesai dipakai harus dicuci agar selalu dalam keadaan bersih dan terawat dengan baik. Bagi petugas harus disediakan pakaian dan perlengkapan kerja seperti pakaian khusus bekerja (overall), sarung tangan, masker, topi, sepatu boot (lars), sapu, dan cangkul garpu. Dalam keadaan darurat bila digunakan truk dengan bak terbuka minimal harus ditutup atau menggunakan jala (jaring) untuk menghindarkan sampah berterbangan saat diangkut(7).

Fungsi kompos selain dapat membersihkan lingkungan dari sampah yang berserakan juga dapat menyuburkan tanah pada tumbuhan tanaman(8). Jika pengolahan sampah non organik dilakukan di Taman Satwa Bali Zoo menjadi kerajinan tangan, hal ini dapat menguntungkan karena selain sebagai pembelajaran tambahan bagi 
wisatawan yang berkunjung dalam proses pengolahan sampah, kerajinan tangan yang menggunakan bahan daur ulang sampah juga dapat dijual pada wisatawan.

Proses pengelolaan limbah cair menggunakan lembar observasi di Taman Satwa Bali Zoo dengan kategori tidak memenuhi syarat karena diketahui hanya memiliki sarana septic tank, serta tidak terdapatnya sarana instalasi pengolahan air limbah. Limbah cair domestik yang berasal dari restoran hanya tersedia sarana tempat penampungan yang kemudian dibawa oleh pihak ke tiga untuk proses lebih lanjut.Pada awalnya tujuan dari pengolahan limbah cair adalah untuk menghilangkan bahanbahan tersuspensi dan terapung, pengolahan bahan organik biodegradable serta mengurangi organisme patogen yang juga terkait dengan aspek estetika dan lingkungan. Pengolahan tersebut dapat dilakukan dengan bantuan peralatan biasanya dilakukan pada Instalasi Pengolahan Air Limbah. Prosespengolahan

IPAL dikelompokkan sebagai pengolahan pertama (Primary treatment) yang bertujuan untuk memisahkan padatan dari air secara fisik menggunakan saringan/filter, pengolahan kedua (secondary treatment) yang bertujuan untuk mengurangi bahan organik dan menghilangkan nutrisi seperti nitrogen dan fosfor, dan pengolahan lanjutan (tertiary treatment) bertujuan untuk menghilangkan nutrisi/unsur hara khususnya nitrat dan posfat, juga sebagai pemusnahan mikroorganisme patogen(6). Sedangkan pada sarana septic tank yang dibuat harus memenuhi ketentuan yakni dinding harus terbuat dari bahan kedap air, pengambilan lumpur minimal empat tahun,harus ada manhole (lubang cek) untuk menguras tangki, danjangan sekali-sekali membuang cairan antiseptik ke septic tank (lisol, karbol wangi, pencuci persolen, deterjen) karena dapat mematikan bakteri anaerob yang mengganggu proses dekomposisi(1). Penilaian keadaan hygiene sanitasi pengelolaan limbah secara keseluruhan baik dari pengelolaan limbah padat (sampah) maupun pengelolaan limbah cairmenggunakan lembar observasi dengan rumus interval kelas di Taman Satwa Bali Zoo didapatkan nilai sebesar 43 dari 61 pertanyaan yakni memenuhi syarat. Namun masih adanya tahap pengelolaan yang tidak memenuhi syarat baik pada sarana tempat sampah, sarana TPS, sarana pengangkut sampah, pengolahan sampah sampai pada kurangnya sarana pengelolaan limbah cair. Limbah cair yang tidak dikelola dengan baik dapat menimbulkan dampak buruk bagi mahluk hidup dan lingkungannya, diantaranya gangguan kesehatan, gangguan terhadap keindahan, gangguan terhadap kerusakan benda(6). Sementara masalah kesehatan lingkungan yang diakibatkan oleh sampah, yakniperkembangbiakan serangga dan tikus, sumber penyakit, dan gangguan estetika(1).

\section{SIMPULAN DAN SARAN}

Berdasarkan dari hasil yang dilakukan tentang pengelolaan limbah di Taman Satwa Bali Zoo dapat disimpulkan bahwa: (1) Proses pengelolaan limbah padat (sampah), sampah yang berasal dari pengunjung disediakan sarana 
tempat sampah yang kemudian diangkut menggunakan sarana pengangkut sampah ke TPS, sampah organik diolah menjadi kompos, sampah non organik dibeli oleh pemulung/dibawa ke TPA Temesi, dan sampah medis dibawa ke pihak ketiga untuk proses lebih lanjut. (2) Proses pengelolaan limbah cair disalurkan langsung pada tempat penampungan tanpa pengolahan lebih lanjut sedangkan pada toilet disalurkan kearah septic tank. (3) Penilaian keadaan hygiene sanitasi pengelolaan limbah secara keseluruhan didapat dari hasil perhitungan interval kelas menggunakan lembar observasi pada proses pengelolaan limbah padat (sampah) dan limbah cair yang sudah memenuhi syarat.

Adapun saran kepada petugas pengelola di Taman Satwa Bali Zoo yakni diharapkan untuk menggunakan sarana tempat sampah yang memenuhi syarat, penggunaan alat pelindung diri, dan menutup sampah ketika sampah diangkut ke TPS, serta diharapkan untuk tetap menjaga kebersihan toilet dan sanitasi limbah di Taman Satwa Bali Zoo,Sukawati, Gianyar.

\section{DAFTAR PUSTAKA}

1. Suyono. Ilmu Kesehatan Masyarakat Dalam Konteks Kesehatan Lingkungan. Jaakarta: EGC.; 2012.

2. Soeparman. Pembuangan Tinja dan Limbah Cair. Jakarta: EGC; 2002.

3. Notoadmodjo. Promosi Kesehatan dan Ilmu Perilaku. Jakarta: Rineka Cipta; 2007.

4. Nazir. Metode Penelitian. Jakarta: Ghalia Indonesia; 2003.

5. Sugiyono. Metode Penelitian Kuantitatif Kualitatif dan R\&D. Bandung: Alfabeta, cv.; 2012 .

6. Sumantri. Kesehatan Lingkungan. Jakarta: Kencana Prenada Media Group.; 2013.

7. Sudarso. Pembuangan Sampah. Surabaya: Proyek Pengembangan Pendidikan Tenaga Sanitasi Pusat.; 1985.

8. Soeryoko. Kiat Pintar Memproduksi Kompos dengan Pengurai Buatan Sendiri. Yogyakarta: Lily Publisher.; 2011. 
